\title{
Corporate Governance Structure And Firm Performance: Empirical Evidence From Brusa Malaysia, Kuala Lumpur
}

Huson Joher, (Email: halahmed@kaau.edu.sa), King Abdul Aziz university, Saudi Arabia Mohd Ali, Universiti Putra Malaysia

\begin{abstract}
The issue of corporate governance has been emerging as important phenomena that has been searched extensively both in developed countries due to its strategic impact on the monitoring of management activities and firms' performance. Yet little attempt has been made in developing countries like Malaysia to ascertain what constitute corporate governance and its impact on firm's performance. Therefore, this study aims at examining the structure of the corporate governance and its impact on firm's performance. This study is based on 100 firms, which are the component of the Composite Index (CI) serve as market barometer. This study employs cross-sectional annual multiple regression model to examine, what constitutes the corporate governance structure and its impact on performance of the firm. The analysis was based on annual regression over 5 years period from 1997 through 2001. Three different blend of surrogate for corporate governance were developed for good corporate governance structure. These are the independent non-executive (outside) directors, audit committee and remuneration committee. To isolate the size effect from the impact of corporate governance structure on firm's performance, firm's size was also included are variable in the model. The ratio of net income before tax to total asset is used as a surrogate for firm's performance. Evidence from the study indicates that there is partial relation between corporate governance structure and corporate performance. The presence of both audit and remuneration committee serves as an important monitoring device to control management activities that lead to increase firm's performance. While on average, the presence of independent nonexecutive directors does not provide any significant explanation for the firm's performance. However, the firm size appears to have significant impact on corporate performance.
\end{abstract}

\section{INTRODUCTION}

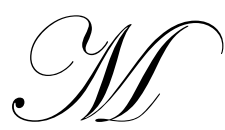

odern corporate finance literature focuses on two competing issues governing the management behaviour. These are agency theory and theory of corporate control. Agency theory posits that there is an inherent conflict of interest between shareholders and managers because of the existence of separation of ownership and control. Jensen and Meckling (1976) in their seminal work on agency relationship propose the idea that agency conflict could have been reduced at a maximum level by making the managers part of the owners. The belief is that once the managers become part of the owners, they will be more responsible in making corporate management decision that will create the value for the firms. The relationship between the good corporate governance structure and firms performance has been the subject of interest and an on going debate due to its strategic implication for the firm's value, and monitoring effect of management activities. This issue has gained a considerable attention in the recent years after the collapse of Enron, a giant utility firm and the collapse of World.com, a worldwide telecommunication giant in the United States of America.

So far there is no universally agreed definition of the corporate governance but tt aims to ensure a process to be implemented within an organisation to direct the company affairs toward business prosperity and corporate accountability. In other words, it aims to maximise shareholders' value where the organisation is managed with prudence and integrity. Since directors are the custodian of the firms and are being elected by the owners to safeguard 
their interest, there is ardent need to examine the board structure and any other forms that self regulate the management activities. Though there is increasing empirical evidence on corporate governance in developed market but little attention has been given in this in less institutionally advanced economies such as Malaysia, to examine what constitutes corporate governance structure and its impact on firm's performance. The rest of the paper is organized as follows: section two provides theoretical and empirical perspectives on corporate governance and firms' performance. Section three briefly describes the data and methodology used in this paper. Findings, conclusion and implication are presents in the section four.

\section{THEORY AND EVIDENCE}

The understanding of the empirical differences in the pattern of corporate governance has advanced in recent years. However, theoretical development in this area of research is yet limited. There is number of studies that attempt to explain theoretically why control is so concentrated with poor shareholders protection in a setting where alignment is the only viable mechanism of corporate governance (La Porta et al. 1999; Bebchuck 1999)). La Porta et al. (2002) make the case for higher concentration of cash flow as a function of quality of investors' protection. However, the empirical evidences suggested three generic measures to control agency problem. These are aligning the managers' incentive with that of shareholders, monitored debt and take over threat. However, this study suggests three blend of governance structures namely, independent board and effective audit and remuneration committee, alignment of managerial interest with those of outside shareholders and block shareholders as external monitoring device to ensure shareholders interests are protected.

The principle of corporate governance promotes the idea of fairness and accountability. The assumption is that the companies that adopt high level of corporate accountability and fairness will have strong and sustained impetus to perform well with greater transparency and hence leaving little room for the agent to mismanage companies' activities which may have detrimental effect on firms' value. Admittingly, there are number of factors identified by both researchers and practitioners alike, to establish a concept of good corporate governance that lead to achieving the companies' objectives based on principle of sound corporate governance represented by effective internal and external control systems, transparency and management competency and competent board of directors. Recently, the introduction of independent non-executive directors as mechanism to control management activities is the latest phenomenon that is attracting the attention of researchers and academics.

The independent (non-executive) directors have similar connotation of not being involved in the day-to-day operation of a company. However, it is highly suspicious that they are truly independent unless they possess right to act independently which is the freedom to express their personal view or they are not under the influence of the top management team or the influential shareholders. Hence independent board serves as a monitoring device to control management activities. The board independent usually requires that members not closely related to the company but have vested economics or financial interest on the firms residuals. Hence this could be further argued that such independent board members can significantly contribute to decision making of the board by bringing more objective view to the evaluation of the performance of the board management. Though, the depth of directors' independence is more formal than substantial, the percentage of independent directors brought on the board is still relatively small minority in most of the developing countries.

In the past, the aspect of including the non-executive directors into board was not given due importance as it was not required by law of the land, nonetheless, imposition of such requirement may encourage greater effective representation of independent non-executive directors among the board. Hence it may bring greater transparency and integrity in the firm activities and reporting. In US, the percentage of outside directors is on the rise while it is a statutory requirement in Malaysia to have 1/3 of the board as the independent and non-executive directors. However, how effective are the independent directors remained illusive in this less institutionally advanced country. This may be because; enforcement of corporate governance practice came into being only in 2000 . Thus the corporate governance is its early stage of the development of good corporate governance culture among the Malaysian companies.

It is important to note that audit committee and remuneration committee presumably could continue to serve as the corporate watchdogs to ensure the management accountability and responsibility towards shareholders by 
ensuring that managers present true and fair view of the firms and avoid irregularities. Therefore, both independent directors and the remuneration committee and audit committee will serve as the blend of good corporate governance structure in creating firm's performance.

More importantly, the issue on the agency problem has been well documented in corporate finance literature. As pointed in the seminal work of Jensen and Meckling (1976), the managerial ownership could serve as a positive monitoring substitute in the agency relation in aligning the managerial interest with those of outside shareholders. They further argued that if there were no debt contracts, agency problem reduces to moral hazard between the manager and owners. Jensen and Meckling (1976) suggested that making the manager the owner of the firm could mitigate againts this basic problem. Since managers (inside owners) have opportunity to earn additional income, they would do so by appropriating additional benefits derived from firms' activities. They have expertise to turn the operating activities of the firms, hence increasing the value of the firm rather than shrinking it. Managers thus have an incentive to choose a good corporate governance structure through which they can nurture investors' confidence as a mean of increasing the firms' value in which their stakes are tied. Thus, the higher level of ownership is a means of realigning the interest of inside shareholders with that of minority shareholders. This, by itself serves as a blend of corporate governance structure. However, Demsetz (1983) and Fama and Jensen (1983a, 1983b) pointed out that higher level of managerial ownership could lead to management entrenchment, because control challenges are difficult to mount by outside stockholders. Following this line of reasoning, Mork et al.(1986) hypothesised a nonlinear relation between manager ownership and corporate performance.

In Malaysia, the ownership concentration has been weak, compared to most developed countries. The institutional ownership accounts for less than $20 \%$ of the outstanding shares (Huson, 2003). Therefore, it is important to determine whether or not such concentration could have any visible impact on corporate governance. Berle and Means (1982) suggest the existence of positive linear relationship between ownership concentration (block shareholding or institutional investors) and firm performance. The issue was later advanced by Shleifer and Vishny (1986), and their result confirms the findings of Berle and Means (1982). Their findings highlighted the important role played by large shareholders as a monitoring device, to control management activities and hence increase the share price of the firms' by increasing the proportion of shares held by these large shareholders. Hill and Snell (1988) showed that ownership structure affect firm's performance as the ownership concentration motivates innovation that leads to value maximization. Hill and Snell (1989) also confirm this positive relation using US firms by taking productivity as a measure of firm's performance. However, the findings of McConnel and Servaes (1990) give contrary view, although their result suggests the existence of certain joint influence of concentration and insider ownership. The findings of Agrawal and Mandelker (1990) support the hypothesis proposed by Shleifer and Vishny (1986) that the existence of large block holders leads to both monitoring of managers and better performance, especially in firms, in which ownership is concentrated in institutional investors. This also serves as another blend of corporate governance structure.

Donaldson and Davis (1991) examined whether the separation of incumbency roles of board chairman and CEO enhanced the protection of shareholders interest. Evidence indicated that the separation of the role of board chairman and CEO would result in separation of power so that no directors will have dominant role in the board. Although this seems to be a driving factor in examining the compliance of corporate governance and corporate performance, however it is not applicable in Malaysian context as CEO is not commonly used in Malaysian incorporation. Exploring on the issue, Benjamin Hermalin and Weisbach_(1991) examined the effects of board composition and direct incentives in public utility firms' performance. Although public utility firms are not profit orientated, the compensation packages for senior managers somehow have impact on firm performance. In early 1990s The relationship between the governance structure and corporate performance has become a hot issue. Catherine Dail and Dalton (1992) focused specifically on the role of founder chief executive officers and the composition of boards of directors on corporate performance. They found some support for the ability of founder and non-founder CEOs to relinquish the tight control and effectively guide the growth of the firms. Their findings suggest that there are strong linkages between the $\mathrm{CEO}$ and directors and firm performance among the largest firms. Furthermore, the evidence also suggests that even strongest linkages are evidenced in the more modestly sized firms. In a similar study, Ezzamel and Watson (1993) again examined the relationship between organisational form, ownership structure and corporate performance using UK companies and two sets of variable. Firstly, they examined 
the extent to which contextual variables such as perceived environment uncertainty and age of the organisational form moderate the relationship between organisational form and corporate performance. Secondly, it examined the possible effects of ownership and control structures on performance. The study had proven that those two measures have direct impact on corporate performance.

To advance on the issue, Anup and Charles (1996) examined seven mechanisms to control agency problems between managers and shareholders. These are shareholdings of insiders, institutions, and large block shareholders, use of outside directors, debt policy, the managerial labour market and the market for corporate control. These mechanisms form part of compliance of corporate governance and make it transparent. The finding shows a significant relationship between firm performance and four of the mechanisms stated above when each is included in a separate OLS regression. While James and Morra (1997) has reviewed the literature on Corporate Decision Making in Canada and concluded that there is no existence of relationship between corporate governance and corporate performance. Similar study undertaken by Regan (1998) and examined the relationship between the board governance and corporate performance. However, no significant relationship was observed between the corporate governance and corporate performance.

The issue was further advanced by Scott and Rosenstein (1998) who examined the relationship between board composition, managerial ownership and firm's performance. The results indicate some support for the curvilinear relationship between managerial ownership and performance posited by Stulz (1988) and empirical findings of Morck, Shleifer and Vishny (1988) and McConnell and Servaes (1990).

In a more recent study, David and Wier (1999) have analysed the extent of Cadbury compliance of corporate governance and its impact on corporate performance in UK firms. Using data for 1992 and 1995 because the UK firms. Evidenced indicates that the duality is less common while firms tend to have more than 3 non-executive directors, there has been an almost universal adoption of board subcommittees such as the remuneration and audit committee. However, it is found that there is a little evidence that the board characteristics recommended by Cadbury has resulted or moved towards an improvement in firm's performance. The only compliance of governance structure that has lead to improved firm performance is the presence of audit and remuneration committee.

\section{DATA AND METHOD OF ESTIMATION}

A sample of 100 firms most of which are drawn from CI component firms which serve as market barometer over the period 1997 through 2001 were studied. The proxies for corporate governance and firms performance are extracted from companies' annual handbook, companies' annual reports and many other sources.

The study uses multivariate regressions model to examine the impact of corporate governance structure on firm's performance. We use annualised regression over a period of 5years. Corporate governance is constituted by diverse board composition proxied by independent non-executive directors, presence of both audit committee and remuneration committee, managerial ownership (director's ownership) and positive monitoring substitute into agency relationship and block shareholding represented by institutional ownership.

\section{Model Specification}

\section{$\mathrm{Y}=\beta_{0}+\beta_{1}(\mathrm{NED1})+\beta_{2}(\mathrm{NED2})+\beta_{3}(\mathrm{NED3})+\beta_{4}(\mathrm{NED} 4)+\beta_{5}(\mathrm{COM})+\beta_{6}(\mathrm{MKTCP})+\beta_{7}$ IOWN $+\beta_{8} \mathrm{DOWN}+\varepsilon$} Where

- $\quad \mathrm{Y}$ - this is corporate performance proxied by level of net income before tax divided firm's total asset

- $\quad$ NED1 - This measures the number of independent non-executive directors (NED) on the board. Cadbury Report by David and Wier (1999) state that independent non-executive directors should have positive influence on the performance of the company. Thus, it is believed that a company with higher number of independent non-executive directors should perform better than companies with smaller numbers. 


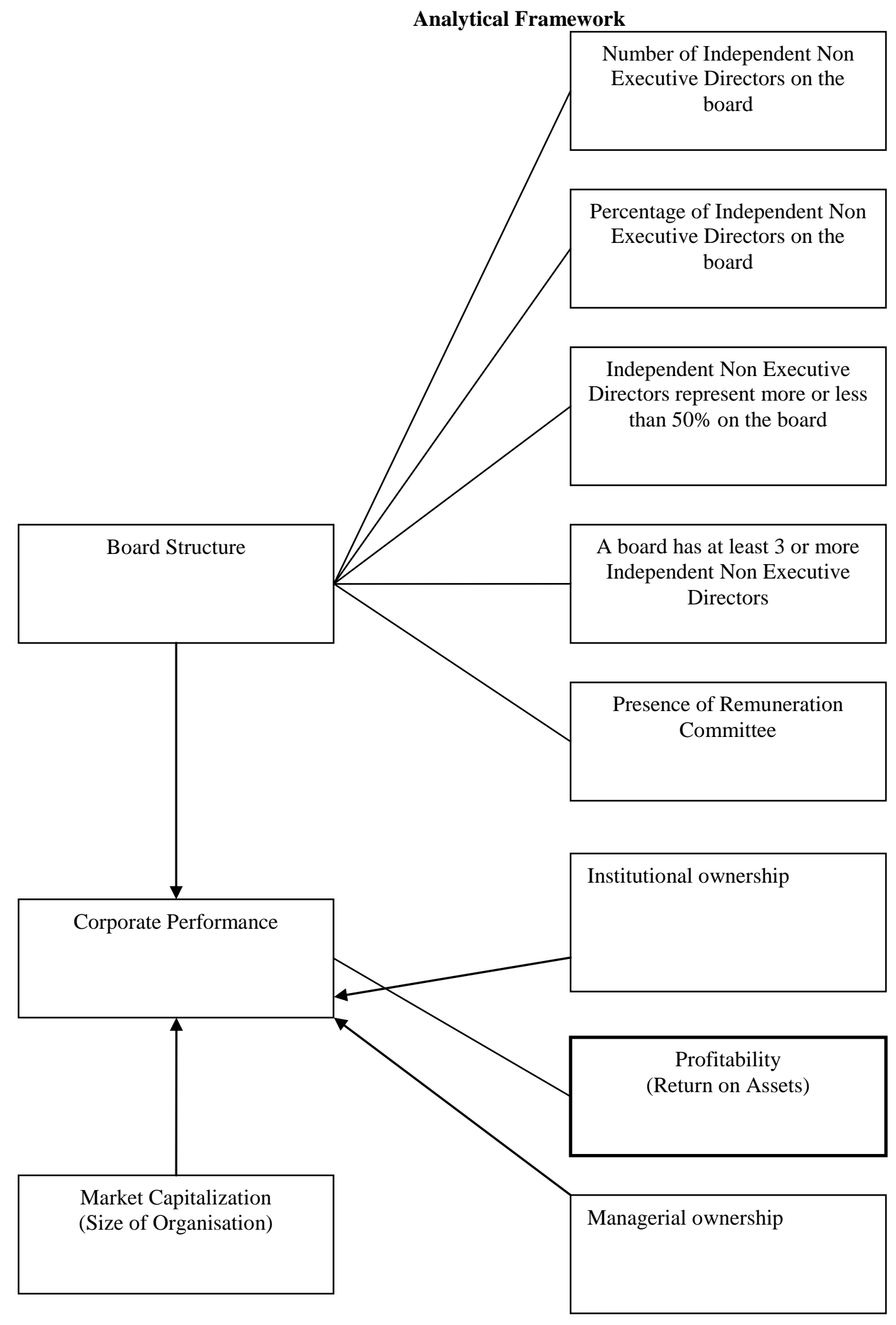


- NED2 - This is the percentage of independent non-executive directors on the board. As independent nonexecutive directors are expected to effectively monitor the executive members, the percentage of independent non-executive sitting in the board is believed to positively influence on the company's performance.

- NED3 - This is the binary variable, which has a value of one if independent non-executive directors represent at least 50 per cent of the board and zero for otherwise. It is expected that organisations with more than 50 per cent of independent non-executive directors would have better monitoring system.

- NED4 - This is the binary variable which has a value of one if a board has three or more independent non executive directors and zero if there are fewer than three independent non executive directors. The Cadbury Committee (UK) recommended that a minimum of three independent non-executive directors is necessary for effective monitoring of the board. It is believed that a firm with at least three independent non-executive directors would perform better than firms with lesser than three.

- $\quad C o m$ - This refers to the presence of audit and remuneration committee. It is a binary variable taking a value of one if a company has both committees and zero otherwise. It is believed that there is positive relationship between the presence of committee and performance

- DOWN- this refers to the percentage of share owned by the directors and it is included to examine the extend to which managerial interest is re-aligned with that of minority shareholders.

- IOWN - this refers to the percentage of ownership control by the institutional investors which serve as a monitoring device to oversee the management activities.

- $\quad M K T P$ - This is the market capitalization measuring the size and it is used as a control measure to analyse the extent of size effects present in the governance structure.

NED1 = Number of Independent Non Executive Directors on the board

NED2 $=$ Percentage of Independent Non Executive Directors on the board

NED3 = Independent Non Executive Directors represent more or less than $50 \%$ on the board (dummy variable).

NED4 = A board has at least 3 or more Independent Non Executive Directors (dummy variable)

$\mathrm{Y}=$ Corporate Performance measured by earnings before tax to total asset abbreviated by ROA.

\section{RESULTS AND DISCUSSION}

Table One: Corporate governance and Firm's Performance, 1997-2001

\begin{tabular}{|c|c|c|c|c|c|c|}
\hline $\begin{array}{c}\text { Variablel } \\
\text { t-value }\end{array}$ & $\mathbf{1 9 9 7}$ & $\mathbf{1 9 9 8}$ & $\mathbf{1 9 9 9}$ & $\mathbf{2 0 0 0}$ & $\mathbf{2 0 0 1}$ & $\begin{array}{c}\text { Average } \\
\text { t-value }\end{array}$ \\
\hline NED1 & $1.7411^{*}$ & 1.4529 & 0.2381 & .3408 & -1.267 & .50118 \\
\hline NED2 & -1.2857 & -.87312 & 2.7880 & .9471 & -1.090 & .0972 \\
\hline NED3 & 1.5667 & -0.8265 & $-3.506^{* * *}$ & -1.168 & .7056 & -.6456 \\
\hline NED4 & -0.6695 & -0.7506 & $-2.3233^{* *}$ & -1.270 & .94495 & -.8137 \\
\hline Com & $2.4454^{* *}$ & $2.73509^{* * *}$ & $2.014^{* *}$ & 1.442 & .68717 & $1.8647^{*}$ \\
\hline MKTCP & $1.9717^{*}$ & 1.1359 & $2.6433^{* * *}$ & 2.746 & 2.6212 & $2.2236^{* *}$ \\
\hline IOWN & -.7965 & -.9156 & .5415 & -.2256 & -.56039 & -.3913 \\
\hline DOWN & -1.6664 & -.9187 & -.380 & -.8767 & -.2824 & -.8248 \\
\hline R-Square & 0.1977 & 0.1705 & 0.224 & 0.127 & .1344 & .17072 \\
\hline
\end{tabular}

$*$, ** indicates significant level at $10 \%$ and 5\% respectively. Average Durbin Watson 2.03. Average F-value 2.37 $(\mathrm{P}=.04954)$

The finding appears to suggest that the presence of both audit and remuneration committees (as proxied for corporate governance structure) does play an important role for the firms performance for the period 1997 to 1999 (economics downturn). However, the presence of independent (non-executive) directors, managerial ownership and block shareholding do not provide any significant account for firm's performance except in year 1999. This could due to fact that in 1999 Malaysian government had undertaken various measures to restore investors' confidence after the 
financial crisis in 1997 and 1998. The firm's size, which is proxied by market capitalization, appears to have significant impact on firm's performance. Thus, corporate governance structure partially explains for the performance of the firms. The percentage of independent non-executive directors is not found to have any significant impact on firm's performance. The institutional ownership, which serves as large shareholders to monitor management activities also, does not provide any explanation for the changes in firms' performance. Furthermore, managerial ownership does not appear to provide any form of control mechanism to enhance firm's performance. The sign of the coefficients are expected and $17.07 \%$ of changes in corporate performance are explained by selected corporate governance variables. The model is significant at 5\% level with the F-value of 2.37.

\section{CONCLUSION}

Corporate Governance is widely accepted worldwide as an important mechanism to control management activities since the publishing of Cadbury Report in 1992 in UK. However, the London Stock Exchange in 1995 and Kuala Lumpur Stock Exchange in only 2000 have adopted the corporate governance practice. As the analysis period consists of 5 years from 1997 to 2001, it may not be able to analyse the effect of compliance of corporate governance by Malaysian Public Listed Companies mostly in 2000. This is because even if the companies have adopted various measures initiated by government to restore investor's confidence, enough space is needed to adapt with the newly adopted corporate culture. Although previous studies in developed market exhibit the existence of relations between governance structure and corporate performance, this study however concludes that there is partial relation between corporate governance structure and corporate performance in Malaysia. While the presence of independent nonexecutive directors, managerial ownership, and institutional ownership do not have any significant impact on firm's performance, however, the firm size appears to have significant impact on corporate performance. Since there no clear cut evidence as to good corporate governance on firms value at this point in time, further searches are needed to ascertain whether adoption of corporate code of conduct in Malaysia result any better performance of the listed firms.

\section{REFERENCES}

1. Anup, A., and Charles, R. K (1996), Firms Performance and Mechanism to Control Agency Problem Between Managers and Shareholders, Journal of Financial and Quantitative Analysis, Vol. 31, No. 3.

2. Benjamin E. H., and Micheal S. W., (1991), The Effect of Board Composition and Direct Incentives on Firm Performance, Financial Management Journal, Winter, pp. 101-112.

3. Bebehuk, L., (1988), A Theory of the Choice between Concentrated and Dispersed Ownership of Corporate Shares, Working Paper, Harvard University.

4. Berle, A., and G. Means, (1932), The Modern Corporation and Private Property, New York, Macmillan.

5. Catherine M. D., and D. R Dalton (1992), The relationship between Governance Structure and Corporate Performance in entrepreneurial firm, Journal of Business Venturing, Vol. 7, No. 5, pp. 375-386.

6. David L., C. Weir, (1999), Governance structure, Size and Corporate Performance in UK firms Management Decision.

7. Demsetz, H., (1983), The structure of corporate ownership: causes and consequences, Journal of Political Economy, vol. 93, pp. 1155-1177.

8. Fama, E., and M. Jensen, 1983, Separation of Ownership and Control, Journal of Law and Economics, Vol. 26, pp. 301-325.

9. Huson. J., and Shagir, (2003), Managerial ownership concentration and Agency Conflict: A test of managerial ownership, risk taking, debt policy and dividend policy, Paper presented at the $5^{\text {th }}$ Annual Symposium of the Malaysian Finance Association.

10. Jensen, M., and W. Meckling, (1976), Theory of the Firm: Managerial Behaviour, Agency Cost and Ownership Structure, Journal of Financial Economics, Vol. 3, pp. 305-360.

11. James, G., and D. Morra (1997), Does Corporate Governance Matter, Business Quarterly, Vol. 61, No. 3.

12. La Porta, R., F. Lopez-De-Silane, and A.Shleifer, (1999), Corporate Ownership Around the World, Journal of Finance, Vol. 52 (July), pp. 1113-1155.

13. La Porta, R., F. Lopez-De-Silane, and A.Shleifer and R.W. Vishny, 2002, Investors Protection and Corporate Valuation, Journal of Finance, Forthcoming. 
14. Mahmoud, E., and R. Watson (1993), Organizational Form, Ownership structure and Corporate Performance: A Contextual Empirical Analysis of UK companies, British Journal of Management, Vol. 4, pp. 161-176.

15. McConnel, J.J and Servaes, H. (1990), Additional Evidence on Equity Ownership and Corporate Valuation, Journal of Financial Economics, Vol. 27, pp. 595-612.

16. Morck, R., A. shleifer and R.W. Vishny (1988), Managerial Ownership and Market Valuation: An Empirical Analysis Journal of Financial Economics, Vol. 20, pp. 293-315.

17. Ned Regan (1998), Board Governance and Corporate Performance: Assessing the Connection, Directorship, Vol. 24, No. 3.

18. Shleifer, A., and R.W. Vishny, (1986), Large Shareholders and Corporate Control, Journal of Political Economy, Vol. 94, pp. 461-488.

19. Stulz, R., (1988), Managerial Control for Voting Right: Financing Policies and Market for Corporate Control, Journal of Financial Economics, Vol. 20, pp. 25-54.

\section{NOTES}

